Jambura Journal of Community Empowerment (JJCE)

Volume (1) Nomor (2), (Desember) (2020), Halaman (112-121)

ISSN (e): 2721-0480

DOI : $\underline{\text { https://doi.org/10.37411/jice.v1i2.464 }}$

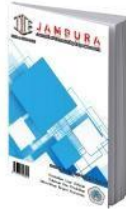

\title{
Dampak Penambangan Pasir Terhadap Kelestarian Lingkungan Di Kelurahan Tumbihe
}

\author{
Melviyana Hulukati ${ }^{1}$, Abd. Hamid Isa ${ }^{2}$ \\ Jurusan Pendidikan Luar Sekolah, Fakultas Ilmu Pendidikan, Universitas Negeri Gorontalo \\ infomelviyana@gmail.com, abdhamidisa@yahoo.co.id
}

Received: 18 Agustus 2020; Revised: 23 Agustus 2020; Accepted: 28 Desember 2020

\begin{abstract}
The problem in this study is how the impact of sand mining on environmental sustainability in Tumbihe Village, Kabila District. This study aims to describe the impact of sand mining on environmental sustainability in Tumbihe Village, Kabila District. To get answers to the above problems, researchers used qualitative methods, data collection techniques in the form of observation, interview techniques, and documentation. The results showed that the impact of sand mining on environmental sustainability in Tumbihe Village, Kabila District, Bone Bolango Regency, basically gave a positive impact in the form of increasing income for miners and the ease of fulfilling local sand materials at cheaper prices and short ordering times. On the other hand, the negative impact felt by the community is mostly through the sand mining business which can result in environmental damage in the form of damage to the land around the community, disturbance of flora and fauna, disturbance of health and safety of the population, landslide prone land and the potential for flooding, air pollution in the form of dust and clean water pollution, as well as roads damaged by the sand transporting route that crosses the area around the population.
\end{abstract} Keywords: Sand mining, environmental sustainability.

\begin{abstract}
ABSTRAK
Permasalahan dalam penelitian ini adalah bagaimana dampak penambangan pasir terhadap kelestarian lingkungan di Kelurahan Tumbihe Kecamatan Kabila. Penelitian ini bertujuan untuk mendeskripsikan dampak penambangan pasir terhadap kelestarian lingkungan di Kelurahan Tumbihe Kecamatan Kabila.Untuk mendapatkan jawaban terhadap permasalahan di atas, peneliti menggunakan metode kualitatif, teknik pengumpulan data dalam bentuk observasi, teknik wawancara, dan dokumentasi. Hasil penelitian menunjukkan bahwa dampak penambangan pasir terhadap kelestarian lingkungan di Kelurahan Tumbihe Kecamatan Kabila Kabupaten Bone Bolango pada dasarnya memberi dampak positif berupa penambahan pendapatan bagi penambang dan mudahnya terpenuhi material pasir lokal dengan harga lebih murah dan waktu pemesanan yang singkat. Disisi lain dampak negatif yang dirasakan masyarakat lebih banyak melalui usaha penambangan pasir tersebut yang dapat mengakibatkan kerusakan lingkungan berupa rusaknya lahan sekitar masyarakat, terganggunya flora dan fauna, terganggunya kesehatan dan keamanan penduduk, lahan rawan longsor dan potensi terjadinya banjir, terjadinya polusi udara berupa debu dan pencemaran air bersih, serta jalan menjadi rusak akibat jalur transportasi pengangkut pasir yang melintasi wilayah sekitar penduduk.
\end{abstract}

Kata Kunci: Penambang pasir, kelestarian lingkungan.

(C2020 Melviyana Hulukati, Abd. Hamid Isa Under the license CC BY-SA 4.0

\section{PENDAHULUAN}

Pendidikan Luar Sekolah mempunyai peranan atau andil dalam memberdayakan masyarakat melalui program-programnya yaitu pendampingan 
sosial dalam kegiatan pemberdayaan. Ada lima strategi yang dapat dilakukan oleh tenaga pendidikan luar sekolah dalam kegiatan pendampingan masyarakat seperti yaitu pemungkinan, penguatan, perlindungan, penyokongan dan pemeliharaan. Strategi tersebut dinilai telah memberikan kontribusi yang cukup berarti bagi kaum miskin dan tertinggal untuk mandiri dan meningkatkan kulitas hidupnya.

Lingkungan hidup adalah kesatuan ruang dengan semua benda, daya, keadaan, dan makhluk hidup, termasuk di dalamnya manusia dan perilakunya. Lingkungan hidup tidak bisa dipisahkan dari ekosistem atau sistem ekologi. Ekosistem adalah satuan kehidupan yang terdiri atas suatu komunitas makhluk hidup (dari berbagai jenis) dengan berbagai benda mati yang membentuk suatu sistem. Manusia adalah bagian dari ekosistem (Setiadi dalam Rusdiana, 2012: 140). Namun, dari sisi lingkungan hidup, aktivitas pertambangan dianggap paling merusak dibanding kegiatan-kegiatan eksploitasi sumber daya alam lainnya, sebab pekerjaan penambangan tidak lebih dari kegiatan melakukan penggalian tanah/bumi untuk mengambil objek penambangan.

Tradisi penambangan pasir secara liar yang dilakukan penduduk yang dilakukan tentunya akan memberikan dampak yang besar terhadap lingkungan. Untuk itu, masalah penambangan pasir patut diangkat menjadi masalah yang perlu dikaji olehkarena banyak sekali di daerah Indonesia yang memanfaatkan pasir sungaisebagai lahan pencari keuntungan secara ekonomi.

Kabupaten Bone Bolango termasuk daerah yang masyarakatnya melakukan penambangan pasir untuk diperjual-belikan demi memenuhi kebutuhan pembangunan masyarakat. Sebagai contoh sebagian masyarakat di Kelurahan Tumbihe Kecamatan Kabila Kabupaten Bone Bolango melakukanpenambangan pasir di beberapa titik yang berada di pinggiran sungai. Masyarakat lokal hanya memikirkan keuntungan semata tanpa memperhatikan kelayakan lingkungan hidup dan masyarakat sekitar. Permasalahan pokok yang terjadi di lokasi penambangan pasir secara ilegal dan tanpa izin dimana oknum penambang pasir melakukan pengerukan pasir di seluruh badan sungai. Tidak ada pengawasan dari pihak pemerintah daerah maupun pemerintah desa setempat untuk mengatur dan mengawasi aktivitas penambangan pasir yang dilakukan oleh masyarakat, terlebih 
lagi aktivitas penambangan pasir tidak dilaksanakan sesuai dengan peraturanperaturan yang berlaku. Aktivitas penambangan pasir yang dilakukan tidak memperhatikan aspek kelestarian lingkungan.

Akibat dari aktivitas penambangan pasir yang dilakukan oleh sebagian masyarakat lokal tersebut menyebabkan tanah di sepanjang pinggiran sungai menjadi longsor, terjadinya erosi di sepanjang sungai, dan adanya galian dapat memicu terjadinya pelebaran sungai. Jalan-jalan menjadi rusak akibat truk-truk yang bermuatan berat mengangkut pasir. Belum lagi dampak sosial dan dampakdampak lain yang secara tidak langsung ditimbulkan akibat dari aktivitas penambangan pasir tersebut. Masyarakat yang bermukim di sekitar daerah penambangan pasir merasa dirugikan dengan adanya kegiatan tersebut. Seharusnya pemanfaatan sumber daya alam termasuk pemanfaatan lahan untuk penambangan pasir mengacu pada Undang-Undang No. 5 Tahun 1960 tentang Peraturan Dasar Pokok-Pokok Agraria (UUPA), Undang-Undang No. 32 Tahun 2009 tentang Perlindungan dan Pengelolaan Lingkungan Hidup (UU PPLH) dan Peraturan Pemerintah No. 1 Tahun 2017 tentang Perubahan Keempat Atas Peraturan Pemerintah Nomor 23 Tahun 2010 Tentang Pelaksanaan Kegiatan Usaha Pertambangan Mineral dan Batubara, beserta segenap peraturan pelaksanaan lainnya.

Untuk memaksimalkan program perbaikan ataupun reklamasi lingkungan di Kelurahan Tumbihe Kecamatan Kabila, target utama dalam pelaksanaan penelitian ini adalah mengetahui terlebih dahulu dampak-dampak dari aktivitas penambangan pasir terhadap kelestarian lingkungan. Secara keseluruhan aktivitas penambangan pasir dapat menimbulkan dampak positif dan dampak negatif. Pada penelitian ini hanya mengkaji dampak negatifnya saja. Setelah diketahui dampakdampak negatifnya maka akan mudah ditelusuri faktor-faktor penyebabnya. Setelah diketahui faktor-faktor penyebabnya dapat ditetapkan aturan-aturan yang harus dilakukan dan ditaati oleh para penambang pasir agar segala aktivitas penambangan pasir yang berdampak negatif bagi kelestarian lingkungan dapat dihindari atau dicegah. Aturan-aturan yang ditetapkan tersebut perlu diberlakukan secara ketat agar aktivitas penambangan pasir yang dilakukan tidak menimbulkan 
dampak negatif lagi terhadap kelestarian lingkungan. Terkait dengan permasalahan yang dikemukakan tersebut maka penulis melakukan penelitian dengan judul "Dampak Penambangan Pasir Terhadap Kelestarian Lingkungan di Kelurahan Tumbihe Kecamatan Kabila Kabupaten Bone Bolango".

\section{METODE}

Penelitian ini didesain sebagai jenis penelitian kualitatif. Menurut Sugiyono (2013:15), metode kualitatif digunakan untuk mendapatkan data yang mendalam, suatu data yang mengandung makna. Obyek penelitian ini menyangkut aktivitas penambangan pasir di Kelurahan Tumbihe Kecamatan Kabila dan dampaknya terhadap kelestarian lingkungan yang diungkapkan dalam bentuk kata-kata, kalimat-kalimat, paragraf-paragraf, dokumen-dokumen dan bukan berbentuk angka-angka. Obyek penelitian tidak dimanipulasi sehingga dapat berada pada kondisi alami sebagai salah satu kriteria penelitian kualitatif.

Dalam memperoleh suatu data yang sesuai dengan permasalahan yang diteliti maka peneliti menggunakan teknik pengumpulan data sebagai berikut:

1. Observasi

Observasi artinya kegiatan mengamati, menatap benda, kejadian gerak, atau proses. Sutrisno Hadi dalam Sugiyono (2013:145) mengemukakan bahwa, observasi merupakan suatu proses yang kompleks, suatu proses yang tersusun dari berbagai proses biologis dan psikhologis. Dua di antara yang terpenting adalah proses-proses pengamatan dan ingatan.Pengamatan yang dilakukan peneliti yakni pengamatan langsung mengenai dampak dari aktivitas penambangan pasir di Kelurahan Tumbihe Kecamatan Kabila terhadap kelestarian lingkungan sehingga mendapatkan informasi yang diperlukan dalam penelitian ini. Obyek yang diamati (1) aktivitas penambangan pasir, (2) dampak penambangan pasir terhadap lingkungan hidup.

2. Wawancara

Menurut Esterberg dalam Sugiyono (2013:231) wawancara merupakan pertemuan dua orang untuk bertukar informasi dan ide melalui tanya jawab, sehingga dapat dikontruksikan makna dalam suatu topik tertentu. Teknik ini 
digunakan sebagai metode pengumpulan data yang domain dan dilengkapi dengan metode lain seperti lainnya. Melalui wawancara diharapkan dapat memperoleh pandangan tentang objek penelitian. Aspek-aspek yang menjadi pokok wawancara (1) aktivitas penambangan pasir, (2) dampak penambangan pasir terhadap lingkungan hidup.

3. Dokumentasi

Dokumentasi dalam penelitian ini digunakan untuk menyelidiki dokumen-dokumen tertulis untuk memperoleh data-data tentang aktivitas penambangan pasir di Kelurahan Tumbihe Kecamatan Kabila dan dampaknya terhadap kelestarian lingkungan. Bentuk dokumen yang dapat digunakan untuk keperluan penelitian dapat berupa aturan secara tertulis, gambar/foto, video, catatan hasil pengamatan lapangan, audio rekaman, dan berbagai jenis dokumen lainnya.

\section{HASIL DAN PEMBAHASAN}

\section{Hasil}

Dalam kegiatan penelitian, peneliti malukan observasi untuk memperoleh data yang mendukung tentang dampak penambangan pasir terhadap kelestarian lingkungan di Kelurahan Tumbihe Kecamatan Kabila Kabupaten Bone Bolango. Adapun data hasil observasi tersebut diuraikan sebagai berikut:

\section{Sejarah Kelurahan Tumbihe}

Tumbihe sudah ada sejak tahun 1880 jauh sebelum Indonesia merdeka, dulu dikenal dengan kampung tumbihe yang dipimpin oleh seorang Ta'uwa (Kepala Kampoeng Pribumi) pertama bernama Bambango tahun 1808-1822, yang konon menurut beberapa cerita sejarah dinamakan Tumbihe karena tempat tersebut selalu dilewati oleh Raja. oleh karena itu, beliau selalu melompat-lompat melewati tempat ini maka timbulah tafsiran bahwa yang selalu melompat hanyalah katak-katak dalam bahasa daerah Tumbihe yang jagoan melompat.

Tahun 1808 sampai dengan 1979 Tumbihe status pemerintahannya adalah desa yang dipimpin oleh seorang kepala desa. Seiring dengan 
perkembangan pemerintahan berlaku UU Nomor 5 Tahun 1974 tentang pokokpokok pemerintahan dimana pada waktu itu Tumbihe masih berada dalam bagian dari wilayah pemerintahan Kabupaten Gorontalo sehingga dengan aturan tersebut setiap walayah dalam struktur pemerintahan daerah dibentuk Daerah Pembantu Wilayah, dan Kecamatan Kabila merupakan pusat central sebagai daerah pembantu Bupati Wilayah II sehingga dengan syarat dalam UU tersebut daerah pembantu Bupati harus berada dalam kawasan Desa swakarya, dimana ada 4 desa dikabila dibentuk manjadi kelurahan, yakni Pauwo, Oluhuta, Padengo, dan Tumbihe.

\section{Kondisi sosial}

Kehidupan masyarakat masih tergolong pada masyarakat dibawah garis menengah kebawah khususnya masyarakat yang tergolong keluarga miskin yang berdasarkan data statistik di tahun 2009 masih mencapai 240 kepala keluarga miskin sebagai pengundang masalah ditinjau dari aspek kondisi sosial ekonomi yang ada sangat memprihatinkan. Mengingat potensi yang dimiliki antara lain minat untuk bekerja dan berusaha cukup besar maka secara eksternal lembaga-lembaga Desa dan organisasi sosial sementara membantu dan membina untuk memberdayakan kelompok masyarakat yang tergolong tidak mampu.

\section{Kondisi ekonomi}

Dilihat dari tata guna yang dimanfaatkan oleh penduduk Kelurahan Tumbihe yang sebagian besar adalah lahan pertanian, menunjukkan bahwa masyarakat mayoritas bekerja sebagai petani dan buruh. Tanaman unggulan meliputi tanaman pangan yaitu jagung, cabai, serta tanaman Tahunan seperti Kelapa, dan Kakao/cokelat.

Berdasarkan hasil penelitian, telah diperoleh data dan informasi tentang berbagai Dampak Penambangan Pasir Terhadap Kelestarian Lingkungan Di Kelurahan Tumbihe Kecamatan Kabila Kabupaten Bone Bolango dengan mewawancarai para pemerintah Desa, para penambang, dan masyarakat. Berbagai sudut pandang atau pendapat yang berbeda-beda yang diungkapkan mengenai Dampak Penambangan Pasir Terhadap Kelestarian Lingkungan Di Kelurahan 
Tumbihe Kecamatan Kabila Kabupaten Bone Bolango. Jadi Dampak Penambangan Pasir Terhadap Kelestarian Lingkungan ini dilihat dari beberapa indikator yang mendukung dalam penelitian ini adalah sebagai berikut:

\section{Rusaknya Lahan (Menjadi Tandus dan Kritis)}

Berdasarkan hasil penelitian menunjukkan bahwa penambangan pasir berdampak pada rusaknya lahan berupa longsornya tebing-tebing tanah ataupun menjadikan cekungan-cekungan dipinggiran sungai sehingga berpotensi juga terhadap banjir. Selan itu, berdampak negatif pada keseimbangan dan fungsi lingkungan seperti menyebabkan terjadinya pengikisan terhadap humus tanah, terbentuknya lubang-lubang besar dan mengakibatkan erosi. Erosi merupakan proses alami yang mudah dikenali, akan tetapi erosi bisa diperparah oleh aktivitas manusia seperti kegiatan penambangan pasir karena pada kegiatan ini terjadi perubahan tutupan lahan menjadi lahan terbuka, sehingga tingkat erosi di daerah sekitar penambangan pasir semakin tinggi dan dapat merugikan masyarakat lingkungan sekitar.

\section{Terganggunya Flora dan Fauna}

Dari hasil penelitian menunjukkan bahwa penambangan pasir memiliki dampak juga terhadap ekosistem hewan dan tumbuh-tumbuhan terutama yang hidup disekitar penambangan pasir. Hal yang paling dirasakan oleh masyarakat adalah dengan adanya penambangan pasir tersebut, ikan-ikan yang hidup di seputaran sungai perlahan mulai punah akibat penggunaan masin yang dilakukan untuk menyedot pasir, yang tentunya mesin tersebut menggunakan bahan bakar yang dapat mencemari air yang ada disungai Bone, sehingga berdampak juga terhadap hasil tangkapan ikan disungai yang digeluti oleh masyarakat yang sering menangkap ikan.

\section{Terganggunya kesehatan dan keamanan penduduk}

Dari aspek kesehatan dan keamanan penduduk yang diakibatkan oleh penambangan pasir menunjukkan bahwa dengan keberadaan penambangan pasir yang ada di Kelurahan Tumbihe dari sisi kesehatan nampak pada jalanjalan yang dilalui truk pengangkut pasir yang lalu lalang secara terus menerus juga mengakibatkan rusaknya jalan dan polusi udara terutama saat musim 
kemarau sehingga berimbas pada kesehatan masyarakat sekitar. Adapun dari aspek keamanan nampak pada suara mesin diesel penyedot yang mengganggu pendengaran sehingga masyarakat merasa bising dan risih dengan keberadaan proses penambangan pasir tersebut. Namun karena tututan ekonomi dan kebutuhan menjadikan masyarakat mau menerima keberadaannya dan perlahan hal tersebut menjadikan masyarakat menjadi terbiasa dengan kondisi kebisingan tersebut.

\section{Lahan rawan longsor dan potensi terjadinya banjir}

Dampak dari penambangan pasir juga berimbas pada keberadaan lahan yang rawan longsor dan potensi terjadinya banjir, dimana kondisi area yang sering digali untuk penambangan pasir semakin dalam. Tingginya pengambilaan sumberdaya alam di sektor pertambangan pasir ini dapat mempercepat kerusakan lahan dalam waktu yang relatif singkat. Hal ini akan mengakibatkan merosotnya kualitas lingkungan. Walaupun areal bekas tambang dapat dimanfaatkan untuk kegiatan ekonomi lainnya namun tetap akan merubah keseimbangan tata lahan lingkungan. Apabila kegiatan penambangan terbuka di daerah resapan air maka dapat menyebabkan terganggunya sistem tata air pada kawasan yang mungkin jauh lebih luas dari kawasan itu sendiri dan beresiko mengakibatkan banjir dan merugikan masyarakat.

\section{Terjadinya polusi udara berupa debu dan pencemaran air bersih}

Berdasarkan hasil penelitian menunjukkan bahwa penambangan pasir berdampak pada polusi udara, dimana hal tersebut bagian dari dampak fisik lingkungan dengan adanya polusi yang berasal dari asap mesin penyedot dan aktivitas lalu lalangnya kenderaan pengankut pasir sehingga mengakibatkan polusi udara terutama saat musim kemarau. Selain itu dengan adanya kegiatan penambangan pasir menjadikan kondisi dan kualitas air bantaran sungai Bone kotor dan tercemar dengan limbah yang bersumber dari mesin penyedot pasir. Hal tersebut tentunya sangat berpengaruh terhadap ekosistem lainnya yang ada di wilayah yang dialiri oleh sungai tersebut. 


\section{Jalan menjadi rusak}

Berdasarkan hasil penelitian menunjukkan bahwa dampak lain yang dirasakan bagi masyarakat melalui aktivitas penambang pasir adalah merembet pada sarana dan infrastruktur jalan yang sering dilalui oleh kenderaan yang mengangkut pasir. Dengan adanya aktivitas tersebut mengakibatkan banyak jalan rusak yang sering digunakan oleh masyarakat setempat. Keberadaan tersebut juga meresahkan warga karena dengan kondisi jalanan yang sudah rusak dapat beresiko tinggi terjadinya kecelakaan terutama dimalam hari.

Temuan lain dari hasil penelitan menunjukkan bahwa aksi nyata yang dilakukan oleh masyarakat yang terkena dampak negatif diantaranya yaitu upaya melakukan pemulihan dengan cara pengurukan kembali lubang-lubang pasca tambang yang berada di sisitanggul, sekaligus upaya pencegahan dengan cara protes kepada penambang yang masih beroperasi, namun masih ada beberapa oknum penambang yang melakukan penambangan ilegal secara sembunyisembunyi. Di sisi lain pemerintah desa juga sudah berupaya mengajukan pembenahan atau penaggulangan dampak penambangan pasir ilegal dengan pengajuan proyek pembuatan tanggul sungai yang berstruktur cor kepada pemerintah Daerah, namun hingga saat ini belum terealisasi

\section{SIMPULAN}

Berdasarkan uraian hasil penelitian dan pembahasan dapat disimpulkan bahwa dampak penambangan pasir terhadap kelestarian lingkungan di Kelurahan Tumbihe Kecamatan Kabila Kabupaten Bone Bolango pada dasarnya memberi dampak positif berupa penambahan pendapatan bagi penambang dan mudahnya terpenuhi material pasir lokal dengan harga lebih murah dan waktu pemesanan yang singkat. Di sisi lain dampak negatif yang dirasakan masyarakat lebih banyak melalui usaha penambangan pasir tersebut yang dapat mengakibatkan kerusakan lingkungan berupa rusaknya lahan sekitar masyarakat, terganggunya flora dan fauna, terganggunya kesehatan dan keamanan penduduk, lahan rawan longsor dan potensi terjadinya banjir, terjadinya polusi udara berupa debu dan pencemaran 
air bersih, serta jalan menjadi rusak akibat jalur transportasi pengangkut pasir yang melintasi wilayah sekitar penduduk.

\section{DAFTARPUSTAKA}

Hatimah, Ihat \& Sadri. 2014. Pembelajaran Berwawasan Kemasyarakatan. Jakarta: Universitas Terbuka

Hosio, J.E., 2007. Kebijakan Publik \& Desentralisasi : Esai-esai dari Sorong. Yogyakarta : Laksbang Yogyakarta

Hosio, JE. 2007. Kebijakan Publik dan Desentralisasi. Laksbang. Yogyakarta.

Rusdiana. A. 2012. Ilmuv Sosial dan Budaya Dasar. Bandung: Pustaka Tresna Bhakti.

Undang-Undang Nomor 23 Tahun 1997 tentang Pengelolaan Lingkungan Hidup. Jakarta.

Undang-Undang Nomor 4 Tahun 2009 Tentang Pertambangan Mineral dan Batubara.

Sugiyono. 2013. Metode Penelitian Kuantitatif, Kualitatif dan $R \&$ D. Bandung: Alfabeta. 